\title{
Transacting Memory in the Digital Age: Modernity, Fluidity and Immateriality
}

\author{
Yasmin Ibrahim ${ }^{1}$
}

Received: 14 February 2018/Accepted: 13 March 2018/Published online: 2 April 2018

(C) The Author(s) 2018

\begin{abstract}
The incessant flow of content and data through digital platforms implicates humanity to immaterial modes of transacting identity and memory. Through the image of the "Napalm Girl" this paper traces the ways in which iconic images and memory can be remediated through social media platforms and algorithms. The re-contextualisation of history and memory through a technological gaze implicates us within new forms of vulnerabilities. By reviewing the politics of looking and watching online in digital platforms, the paper invites us to ponder over the flattening of memory and history through algorithms and a "digital morality" and "mortality" encoded through "user agreements" and "community standards". The repressing of this moral gaze weaves us into a social media economy where morality and ethics are refashioned through a viral economy where images are circulated, altered and reframed through digital technologies. The wider implications of this "virality" for humanity, memory making and historicity are explored.
\end{abstract}

Keywords Fluidity $\cdot$ Immateriality $\cdot$ Modernity $\cdot$ Algorithms $\cdot$ Social memory

\section{Introduction}

The ubiquitous imaging of our everyday lives through mobile devices in the age of convergence has created a fluidity between our visuality and our modes of production online. As we capture and upload images pervasively through mobile technologies, we are forming new intimacies with immateriality in modernity through digital platforms. This fluidity and the binding of immateriality are also

Yasmin Ibrahim

y.ibrahim@qmul.ac.uk

1 Queen Mary University of London, London, UK 
entwined with the production of social memory through people's repositories which sit alongside media memory and the institutionalised memory of the archives or official projects of memory. Institutionalised memory, which has a purposive strand in projects of commemoration, and remembering and forgetting have all come under renewed scrutiny in the digital age as these become disrupted through the "fluidity" of the digital world. Fluidity is defined through both form and meaning in what we identify as a post-human world where algorithms and technologies simulate and anticipate human behaviour while re-calibrating our projects of remembering and forgetting as redemptive acts in human history.

The accumulation of image repositories through people's transactions of the immaterial on digital platforms is consequential in the digital age. Unlike material tangible artefacts like photographs, our relationship with the immaterial online world is about a fluid world where uploads, downloads, storage of memory through mobile devices and cloud systems and the ability to curate images disembedded from its context or origins creates a close intimacy with the immateriality of the digital world. This immateriality is bound with a "virality" where the circulation economy can make new connections between hitherto unrelated objects and subjects through the architecture of the internet where the re-labelling through tags and key words of search terms can enforce new associations between and with the immaterial. As such our human cognitive memory coexists with a mnemonic memory through cloud storage systems and mobile devices. If industrialisation centred a world of materiality, mobility and acceleration, the digital and virtual world presses immateriality as a dominant form where virtuality and invisible labour and consumption can accrue, displacing the material mode as a central aspect of the social reality of production, consumption and asset formation online. The virtual world induces our bind with the fluid and immaterial, where new images can be morphed, curated and relentlessly transacted through a viral economy inviting new forms of gaze and immaterial objects of desire. This fluidity and the emphasis on the immaterial have implications for collective memory and projects of forgetting and remembering, and equally for our constitution of sacred and profane in the virtual world.

\section{Fluidity, Immateriality and Mortality}

Fluidity has been explored within the changing social structures of modernity. Zygmunt Bauman employed the metaphor of "liquidity" to describe a world that has transformed in comparison with its earlier solid state. For Bauman "liquid modernity" defies a particular form morphing into a liquid environment where one cannot rely on any form of fixity, this means individuals cannot rely on past experiences to navigate their futures. This "liquid life is a precarious life, lived under conditions of constant uncertainty" (Bauman 2000: 2). This liquidity then encapsulates the profound transformations taking place in modernity brought through our interconnectivity and processes of globalisation, including the technological transformation brought forth by information and communication technologies (ICTs). We have moved from the stability, permanence and heaviness 
of the "solid" modern era, to the unstable, fleeting era of "liquid" modernity, where maximum impact, instant obsolescence and constant mobility are all importantand from which we cannot escape (Jacobsen and Marshman 2008: 804). Constant disruptions and lack of reliability of the past are encoded in this liquidity where history does not completely work for humanity as a reference point but conjoins to a trajectory of instability.

This liquid modernity stands in contrast to an earlier solid modernity organised through categories and definitions where there is a sense of order or stability. Bauman extends the metaphor of liquidity originally explored by Jean Paul Sartre and Mary Douglas, contrasting the liberating "fluidity" of today with the cloying "viscosity" of life in the past (Jacobsen and Marshman 2008: 805). This liquidity is both liberating and unsettling at the same time, providing new tools and platforms for self-expression and identity formation. This liquidity coalesces with virtuality where information and communications technologies produce new realms to transact and enact sociability through immaterial modes. Capitalism is now linked to the virtual world of information economies and is no longer imagined through heavy industries and factory production, acquiring new forms of fluidity and invisibility in extracting labour and value. The information revolution has implications for the way in which we work and form interpersonal relationships, but more importantly it seeps into other realms of society threatening our existing relationships with social and collective memory.

If liquid modernity is the erosion and blurring of categories such as work and leisure, then the breakdown of distinctions between production, consumption and the production of commodities become reconfigured. What one experiences and consumes "outside" of labour time can become part of the production of commodities (Brouillette 2009: 144-145). The virtual world then stands for a new social world where there is interface between the user and its immateriality. The seamless relationship between production and consumption and the emergence of "prosumer" economies means that the consumer is integrated into the production and marketing modes in invisible and intangible ways. The process of immaterial production is thus cyclical and all-pervasive, incorporating everyone and entails "the whole of the social relation" in the author-work-audience relationship (Brouillette 2009: 144-145). The binding of the social with the co-production of labour and consumption and equally the embedding of these into relations of sociality is a vital aspect of this virtuality. The conjoining of social relations with modes of production is emblematic of the flow of data and content between personal and professional spheres and equally between private and public realms where fluidity is inscribed in the modes of exchange and the different spheres of life.

The virtual space reiterates both the fluidity of liquid modernity, being a space filled with "described" and "made" images. According to Lee et al. (2003: 216) images, represented by the computer, are regenerated by programmatic manipulation after transforming their existence into digital information rather than representing the real like a picture or movie. Hence, the virtual world is a world of simulation (Lee et al. 2003: 216). The virtual space defined through its immateriality is a space of imagery containing the power of transformation in both terms of form and contextual relations between subject and object. 
Derrick de Kerckhove (cf. Mercader 1990: 171-173) proposes four criteria for distinguishing virtual technology, the first being that of immateriality. Secondly, the virtual can be defined as the interval between the limits and options of what is possible. The virtual realm requires the technical establishment of limits and options between what is certain and uncertain. The third attribute refers to cybernetics or the possibility of a system reacting or self-organising itself with the aid of clearly defined protocols and parameters in reference to given tasks. The last aspect is interactivity or the set of options for the parallel and coordinated treatment of data that enables the double intervention of the operator and the device (cf. Mercader 1990: 171-173). Hence, the virtual has modes of manipulation and options within it while binding the certain and uncertain, creating an interface between user, device and the technological platform.

While materiality is understood as the presence of objects, structures and others that comprise one's immediate surroundings, immateriality through its intangibility invites possibilities through its lack of form and structure. In tandem with this, Derrida associates the virtual with a variety of contemporary developments, including "spectral effects, the new speed of apparition (we understand this word in its ghostly sense) of the simulacrum, the synthetic or prosthetic image, and the virtual event, cyberspace and surveillance, the control, appropriations and speculations that today deploy unheard-of powers" (Derrida 1994: xviii). In associating the virtual with ghosts, Derrida positions those immaterial beings as those that haunt the living yet are excluded from them. As ghosts have the ability to upset the natural order of things because of their possession of knowledge that surpasses the living, the virtual, when acknowledged as integral to the constitution of knowledge about the real, similarly has the potential to destabilize what we understand about it (Kim 2013: 3). In destabilizing the assumption that the real is the locus of activity and meaning, Derrida emphasises that the vitality of the immaterial forces of new media is increasingly central to the formation of the real. He implicates the virtual to our experience and conception of the real and how the virtual constitutes our understanding of the real, but is overlooked in our perceptions of it (see Kim 2013: 3).

The nature of electronic information and its immateriality is becoming central to contemporary social, economic and cultural developments in the West. The notion of "virtual reality" than alludes to the nuances in the positioning of the virtual in modernity where it is not only with relevance to technological devices which allow us to enter immersive worlds but also the inextricable bind between virtual and the real in contemporary society. As such reality can be recomposed by virtual processes such that the virtual comes to govern our sense of social reality and relationships. The virtual is a supplement to the real in that the virtual is integral to it, but has been excluded from consideration (Kim 2013: 3-4). Similarly, Baudrillard's conceptualisation of virtual reality as a metaphor for our cultural condition extends his earlier idea on simulation where electronic media encompassing commodity culture and consumer capitalism foreground other traditional sources of value that once grounded truth and meaning. As such virtual reality is constructed out of virtual, immaterial processes, including the flow of electronic images, commodity culture and financial capitalism. For Baudrillard (2008: 35), 
virtual reality and our absorption into it represents our "passing over into the extreme of technology, into technology as an extreme phenomenon". This passing over means that there is no reversibility to an earlier world and neither is there any nostalgia for it. In virtual reality, simulation becomes reality, re-crafting the "immaterial" as flesh (Kim 2013: 4).

Beyond the immateriality and fluidity of the virtual sphere which, Derrida asserts, unleashes a spectral dimension, cyber space is also defined through its ineradicable qualities. This sits in stark contrast with the fluidity of the virtual sphere where content can be manipulated or morphed. The virtual as ineradicable and viral, circulating yet stripped of meaning, portends a new ethereal world where mortality can be re-imagined and morality can be reconfigured through the workings of a host of processes such as algorithms, community standards, lack of editorial oversight and remediation of the moral through new standards of taste and decency. What is unleashed on the internet can circulate forever and this in contradiction with the mortality of human life. The fascination with the virtual is that it defies the mortal time where content can be ineradicable and float forever. While human life is entangled with the project of memento mori, the virtual is about the possibilities of extending the temporality beyond human mortality. Our profiles and expressions on the internet can stay forever, prompting new ways to forget and erase on the internet such as the "right to forget". In May 2014, the European Union found that people can request search engines to remove specific results for queries that include their name, where the interests in those results are outweighed by the person's privacy rights. The right to be forgotten is also known as the right to erasure. It gives individuals the power to request the removal of their personal data when there is no compelling justification for its continued processing by a company. The Data Protection Bill in the UK will enshrine the European Union's General Data Protection Rule (GDPR) ${ }^{1}$ and is intended to give the public more control over what happens with their personal data-including the "right to be forgotten". The bill reveals how machine memory and relentless circulation and ordering of data on the internet have profound implications for societies and individuals. The projects of memory and forgetting online become a complex interplay of machine logic, architecture of the internet and memory as a form of circulation and storage where it is amenable to new forms of governance, control and gaze, and also human vulnerabilities.

\section{The Politics of Virality}

Within the apparitional world of virality, new forms of imagination and reality can be pledged. New worlds and ontologies co-mingle with the inauthentic and simulated versions of the "real". A world where people try to be configured as "real" and "authentic" while being judged by strangers and others who they will never meet in their offline lives. The information revolution unleashed by ICTs is a

\footnotetext{
${ }^{1}$ After 4 years of preparation and debate the GDPR was finally approved by the EU Parliament on 14 April 2016, https://www.eugdpr.org/.
} 
virtual world where matter swims in immaterial mode vying for attention, matter which can recalibrated into new data assemblages which can be resold and commodified in the market economy. With an avalanche of content swimming in the sea of virtuality, what grabs human attention and creates a spurt in the exchanges between people and peers is evidenced in the notion of the viral.

A content that is exchanged, shared widely and rapidly on the intent has been termed viral to capture the spread of its popularity. Viral signifies some form of contagion, analogous to the spread of a biological virus (Anderson and May 1991). What can go viral can defy prediction and lead into the uncertain. With virality being an intrinsic quality of the internet, the phenomenon of seeking to recreate the "viral" is now a big part of marketing. While the viral remains an elusive and unpredictable phenomenon of the virtual sphere, it conjoins with our networked sociality where we are constantly locked into exchanging content where these substitute "small talk" and provide a form of "phatic communion" (Malinowski 1936) where these exchanges become a form of everyday ritual in maintaining social ties. This exchange-based phatic sociality in the online environment as such can turn projects of memory into the "viral" and "popular" where endless exchanges may be less about the content but the creation of resonance through social sharing.

The viral celebrates the popular as part of the social imaginary within a given time. The viral is also about ephemeral until the next viral content claims our attention. The pledging of memory through the viral is also about its reframing through the popular and the ephemeral where new content and exchanges are constantly vying for our attention. The transaction of memory online then binds our projects of memory into new attention economies where the temporal becomes besieged through our ability to hold our attention on material that invokes popular appeal while highlighting that the viral is orchestrated through an elusive logic where what gains popularity is both uncertain and unbound. With the viral becoming newsy - the traditional notion of news becomes reconfigured through rituals of frenetic exchange where the viral is bound up with the phatic, with new forms of sociality and networks which can redirect popular gaze.

The fervent exchanges of content online in different platforms can be seen as a "re-entextualization" (see Bauman and Briggs 1990). This refers to a process by which a piece of "text" is extracted from its original context-of-use and reinserted into an entirely different one, involving different participation frameworks, a different kind of textuality producing different meaning outcomes (Blommaert and Varis 2015). As such what is marginal to the original source of the text can become reconfigured as significant and vice versa. This intense sharing produced through the characteristics of virtuality, particularly immateriality and fluidity, where forms and content remediate our transaction of memory online, locates it as an open-ended phenomenon amenable to manipulation and mutilation by both man and machine. 


\section{Memory and Digital Amnesia}

If the characteristics of the internet such as immateriality, invisibility, virtuality and virality perform as ghosts in a machine, one can imbue the internet with various forms of magic. It is a machine which can offer endless possibilities to re-imagine and resurrect human agency and communion. The saturation of immaterial matter and fluidity, and also the conjoining of these flows of content through human actors who pass this onto others, produces a moment of unlimited arrangements with capital. Our awe with the ghosts in the machine and their ability to transcend time and space is also about capital forging new enterprises with online platforms and its technical architecture. The speed and flow of the internet is also about the complex interplay of capital with human connectivity and our co-optation into the commercial while reconstituting us as data that can be sold and resold.

Within this arrangement of endless awe with virtuality and capital's quest to capitalise on human activities and relationships as well as their free labour, projects of memory and historicity enter into a turbulent realm on the internet. New forms of violence, game play and rituals will engage with these projects of memory, creating new forms of memory and counter-memory. While the internet has enabled people to remember and archive the personal and national, instability and the ghosts in the machine can equally thwart our projects of collection, memorialisation and collective redemption.

I want to interrogate the notion of fluidity of digital immateriality and the implications for social memory through Facebook's treatment of the Napalm Girl image as a pornographic image (see Ibrahim 2017). The iconic image of Napalm Girl went viral again online but for an entirely different reason in 2016. The Pulitzer prize-winning image shot by Associated Press Photographer Nick Ut had been uploaded by Norwegian newspaper editor who had posted the photo as part of a series on war photography and subsequently found his account suspended by Facebook (Ingram 2016). Facebook had coded the iconic war image as a pornographic image through its "technological gaze". Though Facebook had subsequently apologised and restored the image after a public outcry, the act of coding the image as pornographic laid siege to the redemptive power of war photography and the perversity of warfare which targets the flesh of an innocent child.

Facebook has over time defended its transgressions and aberrations by proclaiming that it is a technology company rather than a media organisation, saying that it puts the emphasis on sharing and transacting content rather than on the content's veracity. Recently, Facebook has also been under renewed criticism for fake news in its news feeds. Fluidity and immateriality form an inextricable bind in the Facebook economy as it functions as a platform for sharing, intimacy and maintaining connections with friends and strangers. To sustain these networks through such transactions huge amounts of data and content pass through these sites. As such, friendships, sociality, phatic communion and the sense of self became renegotiated with new rules online while merging with offline norms. These social formations become abstracted by capital where social exchanges of information are 
monetised through the sharing of private data on public platforms. The accumulation and circulation of content provide the means to create huge volumes of traffic where data can be mined and resold to advertisers.

Facebook's shifting modes of identity between a technology company and a platform which handles large amounts of news content inevitably places it in a contested terrain where the practices of sharing in networks coalesce with news dissemination. It becomes intimately implicated in the processes of re-entextualization where context can be stripped out and yet where content can be endlessly circulated, inviting new meanings and readings into historic projects of memory, particularly of images. Facebook's re-readings of iconic images through its "community standards" as such can be irreverent of public sentiments or social and historic contexts and, in the case of the "Napalm girl" incident, iconoclastic. Facebook as a social networking site becomes part of the neoliberal economy's extraction of free labour to boost the agenda of capital, and its algorithms are part of "fixed capital" which intensifies capital accumulation and the monetization of exchange (see Terranova 2014; Davies 2013; Fisher 2009).

As such algorithms can extract not just use value but also aesthetic, existential, social and ethical values (Terranova 2014: 382). Terranova contends users themselves are cast as quasi-automatic relays of a ceaseless information flow (2014: 381) entering a realm of exploitation where free labour is abstracted from leisure pursuits and aesthetic consumption. The Marxist critique of capital's exploitation of free labour on the internet acknowledges the accumulation of content in social networking sites and equally the management of information through algorithms which become an extension of capital's logic to intensify the extraction of value in monetizing networked exchanges. Hence, the algorithm as a form of premeditated logic and formula of capital projects the values of organisations in coding and cataloguing information.

Algorithms as non-neutral entities bear the teeth marks of capital. While discourses of the internet celebrate discourses of empowerment and hold power to account, the intense quest to monetise the internet is also closely related to clandestine algorithms which order information on an industrial scale. Our utopian notions of the internet as open and democratic were in tandem subsumed through the secrecy of algorithms performing to the logic of capital as a form of trade secret which could be protected by commercial regulations. Algorithms as a hidden code behind platforms such as Facebook perform by extracting certain attributes which will drive traffic and maximise a networked attention economy. In view of this, algorithms are complex, hidden, closely guarded, non-static and iterative in moving with the logic of capital (see Diakopoulos 2015; Lievrouw 2012).

Social networking sites as conduits for vast amounts of content without the attendant editorial oversight remain an intrinsic challenge for societies in the digital age. Posing new forms of vulnerability while laying siege to our projects of remembering, forgetting, as well as moments of collective redemption. Facebook has been accused of manipulating trending topics. The company reportedly fired some 18 contractors responsible for curating topics for the list after accusations of bias and replaced them with algorithm (Hovland and Seetharaman 2016). This in turn has facilitated a string of errors including the sharing of hoax stories. 
Facebook's use of algorithms has also been criticised for being amenable to partisan news feeds which spin the news into shareable stories which are inaccurate (Vincent 2016). In response, Facebook has defended itself as a "tech company and not a media company" (Baral 2016). According to Mark Zuckerberg, CEO of Facebook:

When you think about a media company, you know, people are producing content, people are editing content, and that's not us. We're a technology company. We build tools. We do not produce the content. We exist to give you the tools to curate and have the experience that you want, to connect with the people and businesses and institutions in the world that you want. (cf. Baral 2016).

The emphasis on sharing and curation rather than the quality and accuracy of content along with its notion of making content available that is of "public interest" has entrapped Facebook into a long history of social and ethical controversies, particularly with relevance to the image economy on its networking platform. Equally, it is remediated through the technological gaze of social networking sites which can impose their morality and sensibilities through their "user agreements" which act as modes of censorship. The flow of content onto digital platforms will inevitably remediate our notions of the historic and iconic and will equally be a constant threat to our collective constructions of the "sacred".

Facebook's moral governance of images through its community standards has entailed a mix of strategies from employing outsourced censors in the Third World to the use of identification software to recognise known child pornography images to the use of algorithms and the recently discharged human curators of content. The other basis on which it primarily governs images is through its user community standards and its communal gaze as a form of informal policing where people can report objectionable images which will then be assessed against its own internal acceptability standards. With millions of images swimming in its platform and where images attract traffic and the monetisation of data, having a heavy hand or editorial oversight with images is not the desired option for Facebook. Where the algorithm performs as an ahistorical and amoral tracking tool, the community of users are co-opted in policing its platform. This enmeshing of community standards and technological gaze works to organizational rules and the logic of capital where it exploits sharing and exchange networks without value content, not for the content's sake but its ability to be transacted at frenetic pace. Speed of exchange and volume then dictate the logic of capital in exploiting these social networks.

In effect, Facebook extracts aesthetic and moral labour from its users, assessing affect and morality through their reactions while appropriating a paternalistic stance of requesting them to "share and consume responsibly" while commodifying moving and static images as a means to drive traffic and interaction. Hence, its technological gaze is based on constantly testing the boundaries of the sacred and profane, and in the process its technological gaze premises a community standard which is blind to historicity and morality and increasingly a community it may seek to represent.

The constant testing of boundaries where the sacred is desecrated or the profane prevails in the guise of its community standards or "public interest" will entail a 
constant incursion on our collective memory and morality, impressing Facebook's tendency to destroy myths and sacred sites through the cultural violence of flattening content where networks share without knowing or understanding the context or origin of content. Facebook's banning of the Napalm Girl is a representation of this mechanised technological gaze and its attendant morality where the sacred will swim alongside the puerile and pornographic until it is rescued through public outrage and outcry against its cultural iconoclasm.

\section{Ghosts in the Machine}

Patricia Clough (2000: 383) points out that in the age of teletechnology, comprising computer technology and television, these globalised networks of information and communication where layers of images, texts and sounds flow in real time or constitute a reality rather than represent one. In the digital age, the transaction of memory through social networking sites and personalised platforms created for new forms of "sociality" will present new challenges for humanity, particularly in terms of the image and its visuality. In these platforms, the visuality of iconic imagery pressed through the hidden (i.e. algorithms) and explicit modes of sharing will remain in an unstable and turbulent form. As the iconic becomes reconfigured through a technological gaze it will continuously reposition our morality, shifting the historical into new modes of contestation, undoing our collective modes of redemption against acts of human depravity as was evident with the case of the Napalm Girl image.

Given the distinct elements of the virtual environment and our pervasive awe with a new world where technologies can power new forms of fantasy and simulated reality, the real and the virtual as well as the morphed and the sacred will recombine with ferocious speed to thwart and invert our projects of memory. Here, it will be possible to consign new powers to the digital and its magic infused through the "ghosts in the machines" where new types of reality and "worlds" propel us into activities transcending time and space and forming binding relationships with the immaterial. This will call us to invest further into the economies and workings of a system where labour is invisible and tangled through technical data, pledging yet more of our sense and sensibilities to the ghosts that work these machines. These ghosts are the very spirits that work algorithms, the apparitions which enshrine the logic of capital and equally the phantoms which invoke our invisible labour and aesthetics. Through wearable technologies they steer our senses and embed their agenda on human networks and work to relay content and data building up a frenetic pace in which we become part of the machinery, seduced into parting with our labour yet not fully conscious of how our labour is extracted to work this machine.

The embedding of pneumonic memory through storage systems such as clouds and search engines which return semantic searches and build associations with hitherto unrelated events and phenomena, and the flow of the iconic and sacred as envisioned through an image on digital platforms will confront a multitude of ghosts in the machine orchestrated through a co-mingling of capital and technology and equally the insatiable spirit of human animal awed by the invisible and visible 
apparitions of the digital technology. Here in the immaterial world, new instabilities are introduced along with a democratic promise that all users will have access to produce an immaterial world to counter a real world that slots them into class and demographics through material possessions. Antonio Negri, in drawing on Derrida's theory of deconstruction, asserts that capitalism as a system of change collapses the virtual and material world into an undecidable binary while undoing all binaries (see Wilkie 2011: 167-172).

Similarly, Clough (2000:385) drawing on Antony Elliot (1996), asserts that "the human subject's awareness of agencies other than human agency blurs the opposition of human and machine, nature and technology, the virtual and the real, thereby also blurring the opposition of reality and fantasy". As such teletechnology brings about a change for the human subject in the relationship with time and space, and by the extension of that a change in historicity and memory (Clough 2000: 385). This creates a complicit duality where we relay and exchange information which is capitalised by machine algorithms which then reconfigure the sacred. In the process of doing so, we remain equally vulnerable to these arrangements thwarting our projects of memory and history.

\section{Conclusion}

The fluidity and immateriality of the virtual sphere with its ability to reconfigure the human projects of redemption through remembering and forgetting will be disrupted through the ghosts and the invisible processes of the internet. As organizations impose new forms of morality to govern content and to justify it through their protocols and algorithms, the immaterial and fluid web will pose new vulnerabilities where the sacred and profane can be re-coded and re-ordered disrupting continuities with our historicity and collective memorialising. The incursions into the sacred and the constant need to reify and protect the sacred will mean the pervasive testing of our limits and moral boundaries. The ghosts which Derrida alludes to in virtuality are not just about the unlimited knowledge they can potentially hold but the potential to thwart the morality while transacting memory through a sphere which is ineradicable. In the process, it inserts the potential to dislodge the sacred, celebrate the profane and disrupt the moral. The virtual performs to iconoclasm, driven by ghosts which take immaterial forms, while powering these disruptions through social relations and the acts of sharing and communion.

Open Access This article is distributed under the terms of the Creative Commons Attribution 4.0 International License (http://creativecommons.org/licenses/by/4.0/), which permits unrestricted use, distribution, and reproduction in any medium, provided you give appropriate credit to the original author(s) and the source, provide a link to the Creative Commons license, and indicate if changes were made.

\section{References}

Anderson, Roy M., and R.M. May. 1991. Infectious Diseases of Humans. Oxford: Oxford University Press. 
Baral, Susmita. 2016. Is Facebook a Tech or Media Company? CEO Mark Zuckerberg Weighs in. IBT.com, August 8. http://www.ibtimes.com/facebook-tech-or-media-company-ceo-markzuckerberg-weighs-2409428. Accessed 20 Dec 2017.

Baudrillard, Jean. 2008. Perfect Crime. London: Verso.

Bauman, Zygmunt. 2000. Liquid Modernity. Cambridge: Polity Press.

Bauman, Richard, and Charles L. Briggs. 1990. Poetics and performances as critical perspectives on language and social life. Annual Review of Anthropology 19(1): 59-88.

Blommaert, Jan, and Piia Varis. 2015. Conviviality and collectives on social media: Virality, memes, and new social structures. Multilingual Margins 2(1): 31-45.

Brouillette, S. 2009. Creative labor. Mediations 24(2): 140-149.

Clough, Patricia Ticineto. 2000. The Technical Substrates of Unconscious Memory: Rereading Derrida's Freud in the Age of Teletechnology. Sociological Theory 18(3): 383-398.

Derrida, Jacques. 1994. Spectres of Marx: The State of the Debt, the Work of Mourning, and the New International. New York: Routledge.

Diakopoulos, Nicholas. 2015. Algorithmic Accountability: Journalistic Investigation of Computational Power Structures. Digital Journalism 3(3): 398-415.

Davies, William. 2013. Neoliberalism and the Revenge of the "Social". openDemocracy.http://www. opendemocracy.net/william-davies/neoliberalism-and-revenge-of-\%E2\%80\%9Csocial\%E2\%80\% 9D. Accessed 20 Dec 2017.

Elliott, Anthony. 1996. Subject to Ourselves, Social Theory, Psychoanalysis and Postmodernity. Cambridge: Polity Press.

Fisher, Mark. 2009. Capitalist Realism: Is There No Alternative. London: Zero Books.

Hovland, Kjetil, and Deepa Seetharaman. 2016. Facebook Backs Down on Censoring "Napalm Girl" photo. wsj.com. September 9. http://www.wsj.com/articles/norway-accuses-facebook-of-censorshipover-deleted-photo-of-napalm-girl-1473428032. Accessed 20 Dec 2017.

Ibrahim, Yasmin. 2017. Facebook and the Napalm Girl: Reframing the Iconic as Pornographic. Social Media and Society. https://doi.org/10.1177/2056305117743140.

Ingram, Matthew. 2016. Here's Why Facebook Removing that Vietnam Photo is Important. Fortune.com, http://fortune.com/2016/09/09/facebook-napalm-photo-vietnam-war/. Accessed 20 Dec 2017.

Jacobsen, Michael Hviid, and Sophia Marshman. 2008. Bauman's metaphors: The poetic imagination in sociology. Current sociology 56(5): 798-818.

Kim, John W. 2013. Whither the Material in New Media Studies? Communication + 1 2(1): 1-15.

Lee, Sang-Ho, Leem-Jong Jang, and Jin-Goo Kang. 2003. A study of the digital virtuality on El Lissitzky's Proun. Journal of Asian Architecture and Building Engineering 2(1): 215-222.

Lievrouw, Leah A. 2012. The next decade in internet time: Ways ahead for new media studies. Information, Communication \& Society 15(5): 616-638.

Malinowski, Bronislaw. 1936. The problem of meaning in primitive languages. In The Meaning of Meaning, ed. C.K. Ogden, and I.A. Richards, 296-336. London: Kegan Paul.

Mercader, Antoni. 1990. Virtual objects. Temes de Disseny 4: 171-173.

Terranova, Tiziana. 2014. Red Stack Attack! Algorithms, Capital and the Automation of the Common. http://www.euronomade.info/?p=2268. Accessed 20 Dec 2017.

Vincent, James. 2016. Zuckerberg criticized over censorship after Facebook deletes "napalm girl” photo. The Verge. http://www.theverge.com/2016/9/9/12859686/facebook-censorship-napalm-girlaftenposten. Accessed 20 Dec 2017.

Wilkie, Rob. 2011. The Ideology of the Digital Me. In The Digital Condition: Class and Culture in the Information Network. New York: Fordham University.

Dr. Yasmin Ibrahim is a Reader in International Business and Communications at Queen Mary, University of London. Her ongoing research on new media technologies explores the cultural dimensions and social implications of the appropriation of ICTs in different contexts. Beyond new media and digital technologies she writes on political communication and political mobilisation from cultural perspectives. Her other research interests include globalisation, Islam, visual culture and memory studies. 